\title{
A VIOLÊNCIA DOMÉSTICA E A INEFICÁCIA DO DIREITO PENAL NA RESOLUÇÃO DOS CONFLITOS
}

\author{
Janaína Rigo Santin \\ Doutoranda em Direito pela UFPR, Professora do Curso de Direito da UPF. \\ Maristela Piva Guazzelli \\ Professora em Psicologia Clínica, Professora Adjunta do Curso de \\ Psicologia da UPF. \\ Joziele Bona Campana \\ Acadêmica do Curso de Direito, Bolsista do CNPq. \\ Liziane Bona Campana \\ Acadêmica do Curso de Psicologia. \\ SUMÁRIO: 1 Considerações iniciais; 2 A difícil e constante luta pelo reconhecimento \\ do gênero feminino; 3 Atuação do direito penal no combate à violência doméstica; 4 \\ Violência doméstica e cifra negra da criminalidade; 5 Considerações finais; \\ Referências bibliográficas.
}

\section{CONSIDERAÇÕES INICIAIS}

Desde a revolução feminista, a conquista dos direitos da mulher vêm tornandose realidade no contexto brasileiro. Apesar de não contar com a plenitude da proteção almejada, a classe timidamente luta pelo alcance de seus anseios. Muito já fora conquistado, principalmente se analisado o campo de trabalho. No entanto, apesar das inúmeras conquistas obtidas, ainda há um expressivo e considerável número de mulheres que vivem cabisbaixas, suportando a violência, calando-se e aceitando a angústia e o sofrimento com que convivem no seu próprio âmbito familiar, abrindo mão da sua felicidade para atender a premissas de uma cultura patriarcal e machista.

O universo de crimes denunciados e levados ao conhecimento do sistema penal contra o sexo feminino é predominante nas classes sociais de menor potencial aquisitivo; mas, omissamente, há grande violência também nas classes de maior poder aquisitivo. Naquela camada social, as mulheres denunciam por não haver outra escolha; nesta, não querem abalar seu status social e a favorável situação econômica que têm. E assim contribuem para a elevação da cifra negra da criminalidade.

São consideradas também as diferenças de procedimento estabelecidas pelo sistema penal aos crimes cometidos no seio doméstico contra a mulher. Os de "menor potencial ofensivo" estão abrangidos pela Lei dos Juizados Especiais Criminais - Lei $\mathrm{n}^{\circ}$ 9.009/95, enquanto os de "maior potencial ofensivo" são competência da Justiça comum. Mas, apesar de serem regulados processualmente por regras distintas, ambos 
parecem relegar para um segundo plano sua finalidade precípua: a promoção da paz social. Enquanto o primeiro cultiva a impunidade, o segundo a extrapola ainda mais, ao duplicar a vitimização da agredida.

Dessa forma, o presente estudo visa a trazer uma abordagem crítica e reconstrutiva do tratamento atribuído pela dogmática penal à violência doméstica, em especial no que tange à questão do gênero. Urge uma maior conscientização, tanto de homens e mulheres, de que a igualdade entre gêneros, estabelecida na Constituição Federal promulgada em 1988, deve ser uma realidade substancialmente respeitada. É preciso romper laços históricos com o patriarcado e cultuar a igualdade neste País.

\section{A DIFÍCIL E CONSTANTE LUTA PELO RECONHECIMENTO DO GÊNERO FEMININO}

Não é preciso retroceder muito na história para se encontrar marcos da conquista feminina em prol da conquista de seu espaço social.

Apesar de existirem registros de mulheres revolucionárias - a exemplo se destaca LUCRÉCIA MARINELLI, a italiana que, em 1600, defendeu sua classe na obra $L a$ Nobilità e l'Ecclenzza delle Done (A Nobreza e a Excelência da Mulher), ao destacar a importância da Mulher para a construção social, defendendo a igualdade entre sexos -, a conquista de papel de sujeito e não mero objeto, pela mulher, no mundo social e jurídico, deu-se apenas há pouco mais de uma década (BETTO, 2002).

Nos primórdios dos tempos, como observa PIAZZETA (2001), criou-se uma "estória imaginada", baseada em mitos que inferiorizavam cruelmente a mulher, chegando a comparar mulheres revolucionárias como símbolos da perdição. Ao justificar a origem da vida, funda seus argumentos na transformação da personagem Lilith em serpente, uma vez que a mesma tentara recusar o papel submisso que Deus lhe havia confiado. Por descumprimento à ordem, segundo tal fábula, Lilith era a pecadora, condenada a rastejar em forma de serpente, como uma reunião de todo o mal humano.

Nesse mesmo sentido, tem-se na Bíblia Católica a personagem Eva, coincidentemente também mulher, a qual fora colocada na terra exclusivamente para aliviar a solidão vivida pelo homem. Era verdadeiro objeto de satisfação de Adão. E ainda, segundo o livro bíblico, através de seu gesto positivo de oferecer o fruto proibido a Adão, levou toda a humanidade à perdição (PIAZZETA, 2001).

E, ao longo da história, verifica-se, ora de forma mais rígida, ora mais sublime, a inferiorização da mulher, perpetuando sua submissão, relativizando-a a objeto, desmerecedor de qualquer proteção real e igualitária.

Conforme destaca SABADELL (1999), há influência do patriarcado e da esfera privada quando se fala da situação e dos direitos femininos. O patriarcado relaciona-se com a histórica submissão instituída na relação entre os sexos. A esfera privada registra a forma de vivência a que estava adstrita a mulher. Afirma-se que o espaço privado não é objeto de fiscalização social, por ser um ambiente natural, onde as relações são 
supostamente perenes. A única justificativa para a punição a crimes contra a mulher se dava no sentido de que tais crimes "lesam os direitos de propriedade do homem sobre a mulher" (SABADELL, 1999, p. 81). Tal constatação perdurou por muito tempo, podendo ser vistas reminiscências inclusive nos dias atuais.

Na justiça medieval, observa SABADELL, a punição era justificada por ser um "pecado", condenado pelas regras culturais em vigência. Pretendia-se salvar a alma do pecador. Nesse contexto, o corpo da mulher era mero objeto de direito, e apenas como tal merecia proteção. A justificativa de punição dos crimes sexuais era justificada tendo em vista a repercussão que o pecado provocava na sociedade, e não como proteção à vitima (SABADELL, 1999).

Em face ao Renascimento, a mulher da mesma forma era considerada inferior ao homem. Como destaca BETTO (2001), sua inferioridade era considerada natural e, portanto, imutável. Ela jamais, por característica biológica, poderia ser igualada ao homem.

Foi no período iluminista que se inaugurou o feminismo, marcado por reivindicações femininas contra a submissão que lhes era - e ainda é - atribuída. Nessa época, aconteceu a Revolução Francesa, como também a proclamação da Declaração dos Direitos da Mulher e da Cidadã, defendendo a idéia de igualdade entre gêneros e conferindo, ainda que formalmente, direitos naturais iguais entre homens e mulheres. Na oportunidade, como batiza Frei BETTO (2001), houve a formulação de "um contrato social entre sexos", contrato este que vem sendo historicamente violado.

"O movimento feminista organizado surgiu nos EUA, na segunda metade dos anos 60. Logo, expandiu-se pelos países do Ocidente, propugnando a libertação da mulher, e não apenas a emancipação. Qual a diferença? Emancipar-se é equiparar-se ao homem em direitos jurídicos, políticos e econômicos. Corresponde à busca de igualdade. Libertar-se é querer ir mais adiante, marcar a diferença, realçar as condições que regem a alteridade das relações de gênero, de modo a afirmar a mulher como indivíduo autônomo, independente, dotado de plenitude humana e tão sujeito frente ao homem quanto o homem frente à mulher." (BETTO, 2002)

No início da década de 1970, as mulheres estavam se libertando de anos de escravidão e opressão, reivindicando direitos iguais ao homem, tais como um salário igual, o direito ao prazer, a liberdade sexual e o domínio do próprio corpo. BRAGHINI (2000) lembra que, mesmo nesse contexto, as mulheres perdiam de vista que o machismo não era resultado da maldade dos homens, mas de uma ideologia interessada em manter a supremacia de um sexo sobre o outro. Também não foi reconhecida uma possível cumplicidade das mulheres, que eram vistas apenas como vítimas isentas de assumir a responsabilidade pelas próprias vidas. Contudo, existem contradições no discurso feminista, ao pregar a libertação da mulher e ao mesmo tempo reforçar que é vítima, tornando-a incapaz de resolver suas questões.

No Brasil, o feminismo despontou na década de 80 , quando se lutava pela democratização do País. A partir deste momento, começou-se a dar importância à taxa 
elevada de violência doméstica. Na oportunidade, a Rede Globo de Televisão, baseandose nas reivindicações femininas, lançou a minissérie "Quem ama, não mata". Repercutiu também o movimento na criação, em 1985, e breve expansão das Delegacias da Mulher. Dezessete anos pode ser considerado curto período de tempo, quando se trata de adaptação social de uma instituição a um sistema. Na realidade, as Delegacias da Mulher não puderam ser consolidadas de fato - não somente no sistema penal como também na cultura social (BETTO, 2002).

São muitas as conquistas a serem alcançadas. É certo que a classe já deve ser aplaudida, pois qualquer transformação social é morosa, e as mulheres vêm galgando importantes postos em sua luta.

Nas últimas décadas, elas têm conquistado prestígio devido à sua relevante participação na construção do bem-estar mundial. São capazes de exercer tarefas, acrescidas de um sentimento especial, imbuído de paciência e delicadeza, o que, com certeza, resulta em conquistas favoráveis. Essa "fragilidade" feminina, tão necessária à humanização de relações, não pode continuar sendo alvo de abuso dentro de seu mais íntimo âmbito de convívio.

Contentar-se simplesmente com o espaço no campo de trabalho e reconhecimento social-cidadão não basta. Urge a retomada de consciência para que as mulheres sejam reconhecidas primeiramente em seu âmbito familiar, para que, com essa conquista, tenham força e coragem de lutar por maiores anseios.

\section{ATUAÇÃO DO DIREITO PENAL NO COMBATE À VIOLÊNCIA DOMÉSTICA}

O nascimento da mobilização feminina em prol do alcance da justiça tem desvendado deficiências brutais na vida social e principalmente na legislação penal, que se apresentam como barreiras à conquista da igualdade de tratamento entre homens e mulheres prevista pela Constituição Federal de 1988.

É indubitável que as legislações existentes pré-constituição cidadã traziam em si a idéia machista presente durante toda a história da humanidade. O princípio da igualdade instituído por ela é uma verdadeira revolução legislativa, cuja adaptação vem mostrando-se inaceitável frente à grande quantidade de operadores conservadores. A maioria de nossos juristas, infelizmente, ainda são homens, e como todo ser de tal gênero, mesmo que intrinsecamente, mantém em si a vontade de domínio, impedindo a total progressão da interpretação legislativa à luz dos princípios constitucionais. E não são apenas os homens, pois mesmo as mulheres que ascenderam, em decorrência da longa data cultural machista, encontram-se dogmatizadas pelo consenso que impossibilita ascensão e alimenta o preconceito.

Os altos índices de violência familiar revelam a ânsia do homem em se manter no poder e possuir eternamente o domínio; e a mulher, por motivos tais como cultura paternalista e machista, deficiência de meios legais de proteção, discriminação trabalhista - fatores estes que a fazem dependente economicamente, observados principalmente 
em países subdesenvolvidos, mas sem excluir os desenvolvidos - prefere permanecer em silêncio, o que gera gradativamente o crescimento do índice de maus-tratos recebidos.

Nesse sentido, o presente estudo centra-se na vitimização da mulher nas relações intrafamiliares. O que se verifica é uma grande incidência e um descaso para com tais acontecimentos. Prova disso, é o estudo feito pelo IBGE, em que se constatou, no final da década de 80 , que $63 \%$ das vítimas brasileiras de violência doméstica eram mulheres (BERNARDI, 2002).

Salienta-se que a violência intrafamiliar não abre espaços para a libertação, uma vez que a vítima encontra-se sem saídas, tendo que continuar sendo agredida e convivendo com o agressor em razão de vínculos afetivos, familiares e, principalmente, insuficiência financeira para mantenimento de sua vida - dedicada geralmente ao próprio agressor - e da vida de seus filhos.

Pode-se notar, a partir do estudo realizado na cidade de Passo Fundo/RS que, quando se trata de violência entre gêneros, há realmente uma grande incidência de vítimas que convivem com seu agressor (vide Gráfico 1):

\section{Gráfico 1:}

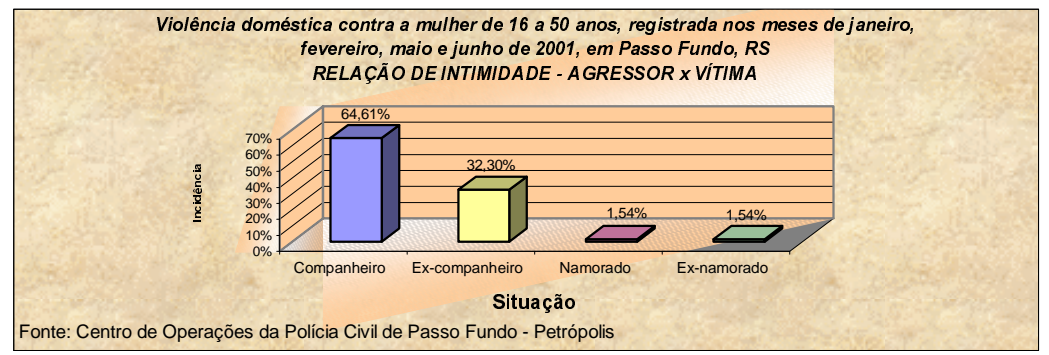

LANZA (2001) define que a união de motivos como dependência - psicológica ou econômica -, desproteção legal e desconfiança com os mecanismos de justiça aplicados, bem como a falta de informação, fazem com que as agredidas permaneçam inertes. Mesmo existindo leis que primam pela igualdade entre gêneros, a sua interpretação distorcida faz com que a jurisprudência ignore a dor da vítima em conviver, diuturnamente, com seu agressor. Corre-se maior risco no espaço "protegido" de seu domicílio do que na rua. A falta de apoio jurisprudencial às vítimas, como bem destaca a autora, faz do estupro um crime duplamente hediondo.

"A justiça, ao abrandar a incidência da lei sobre o réu, acaba penalizando a vítima, e evidencia que ainda existe no judiciário uma postura preconceituosa e discriminatória, estando a jurisprudência a praticar um verdadeiro estupro da lei, um crime duplamente hediondo." (LANZA, 2001, p. 51)

Posturas como essa revelam-se como verdadeiro retrocesso às conquistas femininas. 
Importante destacar que, ao tratar da violência contra as mulheres, está se refletindo sobre agressões que elas recebem pelo fato de serem mulheres. A própria história da humanidade as fez vítimas, frágeis, submissas e, algumas vezes, até de índole desonrosa, merecedoras de violência. Há pouco tempo atrás se excluía a punibilidade do agressor, apoiando-se na legítima defesa da honra. ROSO (1998) cita em seu trabalho um caso em que os jurados acolheram a tese:

"Aliada a outras questões relevantíssimas, amplamente debatidas em plenário, o réu foi absolvido. Acolheu-se, no Tribunal Popular, a tese excludente da ilicitude (antijuridicidade), consistente em legítima defesa (própria) da honra, ficando prejudicado o reconhecimento da legítima defesa putativa, porque a aceitação, pelos jurados, da causa de justificação sobrepõe-se, eliminando a de exculpação, é claro." (ROSSO, 1998, p. 85)

Nesse sentido, o espancamento pode ser visto, pelo agressor, como necessário, a fim de se manter o status quo que, historicamente, considerou a família como uma instituição hierárquica. Os homens precisariam espancar para não ouvir, para não considerar seriamente a posição da mulher, e assim poderiam silenciá-la. O espancamento se traduz no uso de força ou ameaça para que a vítima mude de opinião e não prossiga com a queixa.

O art. $1^{\circ}$ da Declaração sobre a eliminação da violência contra a mulher de 1967 declara que:

"Por 'violência contra a mulher' se entende todo ato de violência baseado no fato da pessoa pertencer ao sexo feminino, que tenha ou possa ter como resultado um dano ou sofrimento físico, sexual ou psicológico para a mulher, inclusive as ameaças, a coação ou privação arbitrária da liberdade." (CAMPOS apud ALVES, 2001, p. 310) ${ }^{1}$

Como se não bastasse a discriminação legal presente na legislação existe, na comunidade feminina, uma verdadeira controvérsia acerca de seus direitos. A impunidade presente leva à sensação de total desproteção. Assim, as poucas leis existentes, que tratam de promover igualdade, são desconhecidas. Há uma verdadeira conspiração para que o patriarcado se mantenha no poder.

É preciso concordar com CABALLERO, que afirma ser "preciso 'denunciar a manipulação ideológica do conhecimento, que coloca os homens orientais como ponto de referência para a compreensão de uma sociedade na qual as mulheres são tratadas como invisíveis, no máximo como coadjuvantes e nunca como sujeitos"' (apudALVES, 2001, p. 314).

Nesse sentido, analisar-se-á como o sistema penal brasileiro trata da violência contra a mulher nas relações intrafamiliares, tendo em vista a existência de crimes considerados de maior potencial ofensivo, abrangidos pelo direito penal comum, e 
infrações de menor potencial ofensivo, abrangidas pela Lei ${ }^{\circ}$ 9.099/95, a qual criou os Juizados Especiais Cíveis e Criminais.

\section{a) Crimes de menor potencial ofensivo}

São consideradas infrações penais de menor potencial ofensivo pela dogmática penal aqueles crimes e contravenções abrangidos pela Lei $n^{\circ} 9.099 / 95$, a que a lei comine pena máxima não superior a 1 (um) ano, excetuando-se os casos em que a lei preveja procedimento especial (art. 61 da Lei n ${ }^{\circ} 9.099 / 95$ ). Salienta-se que tal previsão poderá ser majorada tendo em vista a edição da Lei $n^{\circ} 10.259 / 01$, a qual instituiu os Juizados Especiais Cíveis e Criminais no âmbito da Justiça Federal, a qual em seu art. $2^{\circ}$, parágrafo único, estabeleceu que são infrações de menor potencial ofensivo "os crimes a que a que a lei comine pena máxima não superior a 2 (dois) anos, ou multa".

Em estudo realizado na realidade local sobre violência doméstica, nota-se a grande incidência de registros de crimes abrangidos pela Lei n ${ }^{\circ} 9.099$, de 1995, dentre os quais se enquadram ameaça, lesão corporal leve, entre outros, conforme pode ser observado no gráfico que segue.

\section{Gráfico 2:}

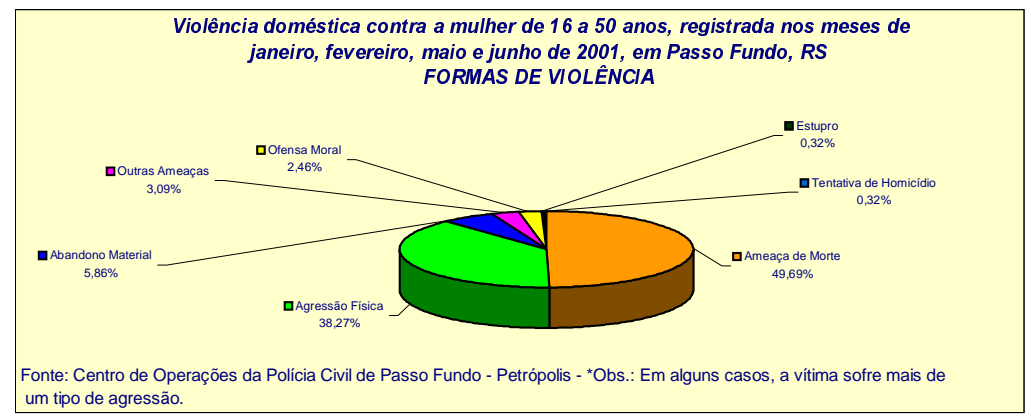

Dessa forma, verifica-se que, dentre as ocorrências de violência doméstica contra a mulher registradas no Centro de Operações da Polícia Civil de Passo Fundo Petrópolis, nos períodos de janeiro, fevereiro, maio e junho de 2001 -, aproximadamente 99\% são infrações abrangidas pela Lei n ${ }^{\circ}$ 9.099/95.

A referida lei, quando publicada, foi saudada e parabenizada massivamente; afinal, era uma saída para agilização dos delitos, uma forma de apaziguar os reclames sociais que condenavam a morosidade da justiça. Destaca SHECAIRA (2000) que a despenalização de fatos, eliminando da esfera punitiva muitos crimes, foi uma saída encontrada pelo sistema penal para resolver o problema da excessiva morosidade e conseqüente sensação de impunidade dos delinqüentes de crimes menos ofensivos. No entanto, o autor acrescenta que ela foi uma máscara para a impunidade que gerou. Além disso, mostra-se como um afronte a princípios constitucionais como o devido processo legal. 
Na sua boa iniciativa, a Lei dos Juizados Especiais Criminais esqueceu-se que todo processo contém regras que, inexoravelmente, precisam ser observadas, em especial quando se trabalha com a esfera penal. O procedimento previsto pela lei sugere pena antes mesmo de saber se o acusado é culpado, induzindo-o a assumir a culpa (SHECAIRA, 2000).

PANDJUARJIAN (2002), sinteticamente, faz um estudo dos procedimentos adotados pela lei. Inicia-se com um Termo Circunstanciado (TC), lavrado na Delegacia de Polícia e encaminhado, juntamente com o autor do fato (o que é seguidamente impossível, considerada a ausência do autor na ocorrência) imediatamente para o Juizado. Cabe observar que o Termo Circunstanciado só será encaminhado se a vítima quiser exercer o seu direito de representação, para o qual tem o prazo decadencial de 6 (seis) meses, após a ocorrência da agressão. Se a vítima optar pela representação imediata, é realizada uma audiência preliminar no Juizado Especial Criminal, onde se possibilitará a conciliação entre as partes. Se concretizada, o acordo será homologado pelo juiz e equipara-se à renúncia do direito de representação, já que é irrecorrível.

Mas se, contrariamente, a vítima permanecer firme em sua decisão de representação, poderá o Ministério Público propor ao acusado, se este preencher os requisitos exigidos pela lei, uma transação penal, com aplicação "imediata" de pena restritiva de direitos ou multa. É direito do Ministério Público, também se atendidos os requisitos legais, propor a suspensão condicional do processo, colocando o acusado em um período de prova por 02 a 04 anos, cujas proibições, faticamente, são gradativamente excluídas no decorrer do tempo. E se, expirado o prazo, o delinqüente não obtiver revogação ou suspensão do prazo por mal comportamento, sua punibilidade considerar-se-á extinta.

"Ela sai da audiência com a nítida sensação de que mais uma vez 'fracassou' na vida e de que não valeu de nada a denúncia. Ao contrário, o agressor sai da audiência vitorioso: 'eu não disse para você que não ia dar em nada?' (...). A violência doméstica que tem adquirido 'status de visibilidade' sofre um retrocesso, com a aplicação desta lei, por ser banalizada, como se bater em mulher fosse algo sem nenhuma importância." (TELES, 2001, p. 02)

Talvez alguns crimes, sejam eles violentos ou não - importante afirmar que, além da violência física há muitos outros fatores a serem considerados -, precisariam ser excluídos de seu âmbito de aplicação. A Lei n ${ }^{\circ}$ 9.099/95 dá à violência doméstica tratamento inferior ao grau de afetação social que ela causa, possibilitando a existência do fenômeno cíclico da violência, desestimulando a mulher a denunciar o seu companheiro, já que vê a justiça tratar a sua dor e o seu problema como uma "briga de bar", esquecendo-se de que o agressor retornará ao convívio familiar, impune e protegido pelo sistema penal.

"A Lei $\mathrm{n}^{\circ}$ 9.099/95 tirou da polícia o poder de inquirir os denunciados. Diante do juiz, a agredida, com medo, recua. E o agressor volta para casa depois de pagar um 'sacolão'. (...) E na maioria das vezes não há lugar sequer para 'esconder' a vítima ameaçada de morte. Os abrigos são insuficientes para colocar todas as mulheres e crianças que estão em perigo de vida. A 'batata quente' vira um problema nosso.” (NEGRÃO; PORTO, 2001, p. 1) 
Defende-se tanto os direitos humanos do acusado, dando a ele garantias penais, constitucionais e processuais, como se a ressocialização da vítima não fosse objetivo básico do Estado "social" de Direito. Esquece-se da vítima e da proteção ou segurança jurídica que o sistema penal deveria lhe conferir.

A grande parte dos problemas em que a mulher é vítima do seu companheiro recai sobre a incidência da Lei dos Juizados Especiais Criminais, e são consideradas infrações de menor potencial ofensivo. Assim, se esquece da vítima, se esquece dos objetivos e anseios por ela esperados, relativizando-a a merecedora da reparação de dano. Considera-se apenas do dano material da infração, relegando a um segundo plano, quando não ao esquecimento, o dano psíquico gerado pelo delito, na maioria das vezes, fardo que a vítima carrega para o resto de sua vida.

Tendo em vista que o poder de seguimento do processo ou seu arquivamento está nas mãos das vítimas, verifica-se que as relações familiares em que estão inseridas vítima e agressor acabam por convencer aquela de que o prosseguimento com a representação possibilitará a concretização das constantes ameaças, além de desgastar a relação familiar, com consequiências danosas aos filhos do casal. Dessa forma, inibese o desejo de ver o agressor punido.

“... a subordinação da persecutio à autorização da vítima nas lesões corporais constitui-se um sério entrave à prevenção geral destes crimes, que servirá, com certeza, se não de instrumento de injustiças, para dificultar em muito realização da justiça." (BALUTA, 2002, p. 01-02)

Tal entendimento vai de encontro ao que dispõe a Magna Carta de 1988, em seu art. 245, o qual prevê a instituição de programas de assistência imediata ou compensação dos danos psicológicos à vítima, instituições quase que inexistentes em nossa sociedade (SALDANHA, 2001).

É urgente que programas de prevenção sejam instituídos. As vítimas de violência precisam de proteção, de incentivo para lutar contra a criminalidade instaurada a seu despeito. Cremos que projeto de lei em tramitação na Câmara que estabelece a notificação compulsória pelos centros de saúde às delegacias, de atendimento à mulheres vítimas de violência, como também aquele, que determina afastamento imediato do agressor do convívio, sejam marcos vitoriosos no combate à violência doméstica.

Também a ressocialização, tanto do agressor, quanto da vítima, merece ser alvo de atenções. Como disse CARRÉ: "todo homem tem seu demônio pessoal, esperando por ele em algum lugar. Não existe homem nenhum aqui, esta noite a quem o crime não se instale em seu coração, se a pessoa errada tentá-lo a isso. Você pode ser o Príncipe Charles, não faz diferença” (apud MENEZES, 2002, p. 01).

Crê-se que existem pessoas com um potencial agressivo maior que outras, e algumas que aparentemente não apresentam esse potencial, mas que por força das circunstâncias cometem atos bárbaros. Tais instintos precisam ser reprimidos pelos meios de controle social, dentre os quais o mais efetivo deveria ser o sistema penal. Se alguém não for capaz de fazê-lo, talvez a saída poderia ser condená-lo a ser submetido 
a terapias que visem a sua readequação ao meio social em que vive e, principalmente, ao seio familiar.

\section{b) Crimes de maior potencial ofensivo}

No que tange à violência doméstica, pode-se dizer que crimes de maior potencial ofensivo são aqueles que não estão abrangidos pela incidência da Lei no 9.099/95.

Nesse sentido, conforme Gráfico 2, verifica-se a ocorrência de lesões corporais (salienta-se que são enquadrados como de maior potencial ofensivo somente as lesões graves e gravíssimas), tentativa de homicídio e estupro (respectivamente arts. 129, 121 c/c 14, II e 213, todos do Código Penal brasileiro).

Com relação ao crime de estupro, é inaceitável que em pleno século XXI existam doutrinadores que crêem ser o sexo dever de casamento, tais como MIRABETE. Já DELMANTO acerta ao dizer que essa regra atenta contra a dignidade da mulher e o respeito no lar. Na esfera cível, a ocorrência de estupro no casamento implica motivo para a separação judicial do casal, mas essa regra civil não significa que o estupro esteja sendo legalizado entre conjugues, na esfera penal. Muito antes o contrário (MENEZES, 2002).

Nesse sentido, convém refletir sobre a real potencialidade do dano causado por um crime de estupro em uma vítima, em contraponto com o valor estabelecido por ele na legislação penal em vigor. Será que marcas deixadas eternamente no corpo, na alma e na dignidade da vítima merecem ser relativizados, como o foram?

Às vezes o descaso das autoridades frente ao problema é mais ofensivo e doloroso para a vítima do que a própria violência sofrida. A impunidade imperante em crimes tais como esse é fator gerador do desprezo e descrédito da sociedade para com o Direito Penal (GAILEWITCH, 2001).

Observa SABADELL que os crimes sexuais, caracterizados como "de maior potencial ofensivo" - sob a ótica da Lei n ${ }^{\circ}$ 9.099/95 - são considerados crime de ação privada. Afinal, como exposto na parte introdutória deste trabalho, direitos femininos levam historicamente à idéia de esfera privada, fazendo com que o gênero em questão seja discriminado descaradamente pela legislação.

VARGAS (2000) enfoca que, nos crimes sexuais, a mulher acaba sendo duplamente prejudicada. É muito difícil o estabelecimento de provas nesse tipo penal, uma vez que a mulher, repugnada pela violência que sofreu, inocentemente, toma banho após o ato, o que impossibilita a coleta de material probatório, tornando sua palavra a única prova existente. Salienta-se o constrangimento provocado pelo referido exame de corpo de delito, necessário para a prova material do crime, quando se encontra num estado psicológico altamente abalado. Como se não bastasse, sofre uma nova vitimização pelo sistema penal, que buscará saber, através da análise de sua vida, seu comportamento, se é digna de receber a proteção legal, se é honesta. Tantas dificuldades acabam sendo óbices intransponíveis para que a mulher denuncie seu agressor. 
Acerca da avaliação da honestidade da mulher, muito há que ser refletido.

Merece aplausos MENEZES (2002), ao analisar decisões da Suprema Corte da Itália que alegavam não ser possível ao criminoso despir sozinho a vítima que usava calças jeans. Tal justificativa é um verdadeiro abuso, tendo em vista que não há descrição no tipo penal da usurpação da vestimenta da vítima como ação exclusiva do estuprador. Tal constatação carece de responsabilidade, tendo em vista a possibilidade de o agressor usar de violência explícita ou ameaças de morte para fazer com que a vítima contribuísse com seu ato. É verdadeiramente inadmissível afirmações como as de SZNICK, afirmando sobre a vítima que "ainda que ela esteja reduzida à impossibilidade (amarrada) não é possível a immissio pênis, se a mulher mantiver as pernas fechadas" (apud MENEZES, 2002, p. 22).

Fundamental para a presente análise a concepção defendida por ANDRADE (1996), que critica o direito penal por ter apenas "funções simbólicas", condicionado por variáveis latentes e não legalmente reconhecidas, que reúnem uma posição estereotipada a respeito da pessoa do autor e da pessoa da vítima. Contenta-se com o reconhecimento da importância da violência contra a mulher, mas direciona a vítima a renunciar ao direito penal, quando deveria ter a função de plasmar os valores da nova moral feminista.

"Num sentido forte, o sistema penal duplica a vitimação feminina, porque além de vitimadas pela violência sexual, as mulheres o são pela violência institucional, que reproduz a violência estrutural das relações sociais patriarcais e de opressão sexista, sendo submetidas a julgamento e divididas. (...) O sistema penal expressa e reproduz, do ponto de vista da moral sexual, a grande linha divisória e discriminatória entre as mulheres tidas por honestas (cidadãs de primeira categoria), que merecem respeito e proteção social e jurídica e as outras (cidadãs de segunda categoria), que a sociedade abandona na medida em que se afastam dos padrões de comportamentos estritos que o patriarcalismo impõe à mulher. De modo que só as primeiras poderão obter do sistema penal o reconhecimento de sua capacidade de vitimização." (ANDRADE, 1996, p. 107)

Nesse sentido, OLIVEIRA destaca que a característica de conhecimento e investigação da vida da vítima preliminarmente ao julgamento do autor é inerente aos crimes contra o costume, nesses casos, a vida da vítima precisa "ser analisada em todos os seus pormenores, desde sua família até seu último relacionamento" (2001, p. 2).

ANDRADE (1996) reforça que o avanço, conquistado através de décadas, foi a mera transformação do abuso contra a classe feminina. O sistema penal é mais do que ineficaz, pois além de não proteger a mulher, duplica a sua vitimização ao interrogá-la a fim de constatar se é digna de proteção do sistema. Assim, os avanços são classificados como ilusórios, pois acaba-se, por força do costume, acusando e julgando a vítima e não o autor, havendo uma seletividade das vítimas, somente sendo dignas de proteção as "mulheres honestas". Há uma total intervenção na intimidade da vítima, a qual passa a ser investigada com vistas a desvendar sua "reputação sexual", a fim de comprovar se não houve "contribuição" para o crime. 
O valor a ser protegido pelo atual sistema penal é a preservação da família, não importa a que preço, e não o sujeito vítima, contrariando toda uma tendência moderna dentro dos demais ramos jurídicos. Viola-se a liberdade sexual feminina através do dispositivo legal "mulher honesta", ${ }^{2}$ o qual obriga ao julgamento antecedente da vítima pelo sistema penal, a fim de se verificar se será possível punir o autor, e se a vítima era digna da proteção do sistema penal (ANDRADE, 1996).

Quando deveria ser forte, o sistema é fraco. Ineficaz, porque não protege a mulher, prevenindo os crimes. Injusto, porque não escuta o interesse da vítima, não compreende a violência sexual, não entende a transformação das relações de gênero. Inócuo, pois dá à vítima titularidade de ação (art. 225 do Código Penal brasileiro) e, no processo, tira-lhe o direito de co-participação. E, numa patente inversão de valores, quando fraco e protecionista deveria ser, se faz forte, ao duplicar a vitimização, atrelandose à cultura discriminatória. Recria desigualdades e preconceitos, embasando-se em uma visão patriarcalista que considera a mulher inferior e subjugada ao homem (ANDRADE, 1996).

Registra a fragilidade do sistema também BUGLIONE (2000), argumentando que o processo de persecução de tipos penais acaba por reproduzir, ou até criar, condutas discriminatórias, instituindo a idéia da mulher como metáfora do direito penal, tendo em vista a indiferença e insignificância das particularidades do sexo, as quais são usadas não para proteger, mas para reprimir.

Convém ressaltar que, em outros ramos do direito, registram-se avanços significativos em relação à questão de gênero. O Direito Constitucional, fundamento de validade dos demais ramos jurídicos, demonstra expressamente tais mudanças, consagrando o princípio da igualdade de todos perante a lei (art. $5^{\circ}$, caput, e art. 226, § $5^{\circ}$ da Constituição Federal) e a vedação de qualquer tipo de discriminação (art. $4^{\circ}$, IV do mesmo diploma legal). E mesmo assim, para o Direito Penal, as mulheres continuam caindo na tentação, continuam sendo "pecadoras".

\section{VIOLÊNCIA DOMÉSTICA E CIFRA NEGRA DA CRIMINALIDADE}

Partindo da premissa de que, uma vez ocorrido o fato descrito na lei, não sendo o agente beneficiado por nenhuma das excludentes da culpabilidade e antijuridicidade, elementos do crime, tal crime aconteceu e, portanto, deveria estar presente nas estatísticas oficiais que informam sobre a incidência de crimes no país.

Segundo dados do Conselho Nacional dos Direitos da Mulher, referidos no artigo "Violência Doméstica terá espaço para debate", no site "Yahoo", a cada quatro minutos uma mulher é estuprada no Brasil. Frente a tal número, como admitir que numa cidade com tantos habitantes, ocorram apenas 2 (dois) estupros domésticos em 4 (quatro) meses? Certamente muitos casos não são registrados. 
Ocorre que, em se tratando de crimes cujo interesse de omissão divulgatória seja "relevante", tais como os cometidos pela alta elite social ou representantes do povo, como crimes fiscais e de colarinho branco, são acobertados e os dados relativos à sua ocorrência não são computados nas estatísticas. $\mathrm{O}$ mesmo ocorre com crimes praticados no interior do ambiente doméstico. O desprestígio familiar, o medo de perda da condição social e econômica, de não ser capaz de dar, sozinhas, educação adequada aos filhos, faz com que as mulheres, vítimas de seus companheiros, contribuam para o alargamento da cifra negra da criminalidade, pois se não registrados nas estatísticas, por não terem sido levados ao conhecimento das autoridades competentes, são dados como inexistentes.

FERREIRA (2002) registra a cifra negra da criminalidade como a diferença obtida entre a criminalidade real e a criminalidade aparente, destacando a contribuição da vítima para sua existência.

"Muitas vezes, a própria vítima tem certa participação no incremento desta cifra negra, por não dar conta da ocorrência do fato delituoso e por considerálo como não delituoso ou não judicialmente punível. Temendo represálias, a vítima não denuncia ou representa, outras vezes não faz uso dos meios judiciais pela existência de meios alternativos (...) geralmente desproporcionais." (FERREIRA, 2002, p. 1)

Afirma MENEZES (2002, p. 02) que a existência da "malsinada cifra negra" é fruto da vitimização secundária a qual está adstrita a mulher estuprada. O sistema a incentiva a permanecer em silêncio, pois acresce danos à pessoa, que já está fragilizada psíquica, física e socialmente com o acontecimento.

De fato, a banalização da violência doméstica certamente contribui para que essa máscara seja montada. Um empurrão, um tapa, uma agressão verbal ou uma ameaça são considerados normais a todo relacionamento, não englobados como típicos de violência.

De outro lado, a perseguição aliada à desproteção à vítima que toma coragem de denunciar é alarmante. Quando há local destinado ao abrigo dessas pessoas, são elas que precisam sair de casa, como culpadas, abandonando filhos, casa, enfim, sua vida. Muitas vezes a situação ainda é mais caótica. Se da inexistência de abrigos protecionistas, elas precisam voltar para casa, para levar novas "surras", sob ameaças, são coagidas a retornar à Delegacia e informar que se reconciliaram com o marido, que ele não teve culpa do incidente, que querem retirar a queixa, já que estavam fazendo isso só para provocá-lo. Para os mais desavisados, pode-se chegar a conclusões como se as vítimas gostassem de ver seu marido, companheiro, namorado ou amigo agressivo, como se gostassem de apanhar, como se a tese do sadomasoquismo feminino fosse uma realidade.

\section{CONSIDERAÇÕES FINAIS}

A violência doméstica é uma afronta aos direitos humanos das mulheres, eis que atinge diretamente a dignidade, a vida, a liberdade e, principalmente, a igualdade prevista pela Constituição brasileira de 1988. No Brasil, constata-se uma notável 
ascensão social feminina, a qual transmite a ilusão de conquista total de igualdade entre gêneros.

É preciso divulgar também o retrocesso da sociedade na busca por mudanças. A violência doméstica revela números inimagináveis e escondidos pelo medo, dependência econômica e ineficácia legislativa, impostos por uma cultura machista e paternalista, os quais ainda não foram resolvidos, a despeito dos avanços feministas conquistados nas últimas décadas.

Enaltecidos com tão singelas conquistas, a sociedade esquece que há um enorme contingente de mulheres que sofrem espancamentos e violência sexual dentro de suas próprias casas. A indagação que se faz é: como se pode enaltecer com avanços, se por detrás deles há uma população imensa de pessoas cabisbaixas - as quais aumentam os números da cifra negra da criminalidade - por não encontrarem solução aos seus problemas e precisarem aceitar o silêncio como a melhor forma de enfrentamento?

Dessa forma, apesar do discurso oficial, o que se verifica, especialmente no âmbito do sistema penal brasileiro, é a presença de uma discriminação inexorável entre gêneros, que precisa ser abolida. As leis defensoras precisam ser reformuladas de forma persuasiva e corajosa, para que realmente não sejam mais que uma mera folha de papel destinada apenas a promulgar boas intenções no aspecto formal, mas que possibilitam uma eficácia somente simbólica no que tange à sua aplicação social, numa autêntica inversão de funções. Não basta a inserção na Constituição Federal de 1988 da igualdade entre gêneros. Há que se inserir essa igualdade no âmbito do sistema penal e na consciência dos agentes que trabalham na persecução penal.

Urge a movimentação social em busca do saneamento destes empecilhos que tornam muitas mulheres escravas de seu próprio ser, da história de gerações e da constante ânsia de poder querido pelos homens. É certo que existem diferenças, e estas devem ser respeitadas, sem contudo ferir direitos tão fundamentais como a dignidade e a igualdade perante a lei.

E ainda, pode-se afirmar que algumas das soluções poderiam ser obtidas através de um inexorável desempenho governamental, com o investimento em abrigos de proteção à mulher violentada, em programas de recuperação psicológica e social do agressor e também da vítima. Tais valores devem ser as premissas básicas em todo País, uma vez que a violência doméstica é geradora de maus exemplos, formadora de criminosos muito mais ofensivos, os quais aumentam as cifras da violência brasileira.

\section{REFERÊNCIAS BIBLIOGRÁFICAS}

ALVES, Teresina Roseli Michaloski. Direitos humanos das mulheres: considerações em torno da conquista da cidadania feminina. Justiça do Direito. Passo Fundo: Ediupf, ano 15, v. II, 2001, p. 307-315.

ANDRADE, Vera Regina de. Violência sexual e sistema penal: proteção ou duplicação da vitimação feminina? Seqüencia, Florianópolis, n. 33, p. 87-114, dez. 1996.

BALUTA, José Jairo. Juizado Especial Criminal: curador especial e colisão de interesses.

Disponível em: http://www.uepg.br/rj/lvlat10.htm. Acesso em 18 maio 2002. 
BERNARDI, Iara. Acabar com a violência contra a mulher é interesse de toda a sociedade. Disponível em: http://www.iarabernardi.org.br/fala8.htm. Acesso em 03 maio 2002.

BETTO, Frei. Marcas de batom: como o movimento feminista evoluiu no Brasil e no Mundo. Revista Caros Amigos. São Paulo, ano V, n. 54, p. 16-17, set. 2001.

BRAGHINI, Lucélia. Cenas repetitivas de violência doméstica: um impasse entre Eros e Tanatos. Campinas: Unicamp, 2000.

BRASIL. Constituição (1988). Constituição da República Federativa do Brasil: promulgada em 5 de outubro de 1988: atualizada até a Emenda Constitucional n ${ }^{\circ} 20$, de 15.12.1998. 21. ed. São Paulo: Saraiva, 1999.

BRASIL. Decreto-Lei $n^{\circ}$ 2.848, de 7 de dezembro de 1940: atualizada até 31.12.2000. 3. ed. São Paulo: Revista dos Tribunais, 2001, p. 239-324.

BRASIL. Lei n 9.099, de 26 de setembro 1995. Dispõe sobre os Juizados Especiais Cíveis e Criminais. Disponível em: http://www.rt.com.br/codigopenal/atualizações.

BUGLIONE, Samantha. A mulher enquanto metáfora do direito penal. Discursos, Porto Alegre, 2000.

DE LANZA, Susana Montoza. Programas de Asistencia a Víctimas de Delitos. Revista Brasileira de Ciências Criminais. São Paulo: Revista dos Tribunais, ano 9, n. 33, p. 203-216, jan./mar. 2001.

DIAS, Maria Berenice. Estupro: um crime duplamente hediondo. Revista Síntese de Direito Penal e Processual Penal. Porto Alegre: Síntese, n. 11, v. 2, p. 51-69, dez./jan. 2002.

FERREIRA, Pedro Luciano Evangelista. Apontamentos criminológicos a respeito da delinqüência. Disponível em: http://www.cescage.com.br/graduação/art.../ apontamentos\%criminologicos.htm. Acesso em 18 maio 2002.

GAILEWITCH, Mônica. O silêncio chegou ao fïm. Cláudia. São Paulo: Abril, p. 14-20, mar. 2001.

MENEZES, Shirlei da Silva. A influência do comportamento da vítima no crime de estupro. Disponível em: http://www.pericias-forenses.com.br/estupro.htm. Acesso em 18 maio 2001.

NEGRÃO, Télia; PORTO, Adélia. E nós com isso? Porto Alegre, 2001.

OLIVEIRA, Flávia Lopes. Estupro (e outros crimes contra a mulher): quem é o réu? Disponível em: http://www.apriori.com.br/artigos. Acesso em 04 maio 2001.

PANDJIARJIAN, Valéria. Juizado Especial Criminal: Lei no 9.099/95. Disponível em: http:// www.mj.gov.br/sedh/cndm/artigos/auto_juizado_especial_criminal.htm. Acesso em 19 jan. 2002. PIAZZETA, Naele Ochoa. O princípio da igualdade no direito penal brasileiro: uma abordagem de gênero. Porto Alegre: Livraria do Advogado, 2001.

RIO GRANDE DO SUL. Secretaria da Justiça e Segurança. Delegacias e postos policiais no combate à violência e garantia dos direitos da mulher. Porto Alegre: Coordenadoria Estadual da Mulher, 2001.

SABADELL, Ana Lúcia. A Problemática dos Delitos Sexuais numa Perspectiva de Direito Comparado. Revista Brasileira de Ciências Criminais. São Paulo: Revista dos Tribunais, ano 7 , n. 27, jul./set. 1999, p. 80-102.

SHECAIRA, Sérgio Salomão. Controle Social Punitivo e a Experiência Brasileira. Revista Brasileira de Ciências Criminais. São Paulo: Revista dos Tribunais, ano 8, n. 29, jan./mar. 2000, p. 401-411.

TELES, Maria Amélia de Almeida. A violência doméstica e a Lei no 9.099/95. Folha Feminista, São Paulo, n. 26, ago. 2001, p. 01-02. 
VARGAS, Joana Domingues. Crimes sexuais e sistema de justiça. São Paulo: IBCrim, 2000. YAHOO NOTÍCIAS. Política. Violência Doméstica terá espaço para Debate. Disponível em: http://br.news.yahoo.com/020404/13/389u.html. Acesso em 03.maio.2002. 